\section{The Relational View: Future challenges for a non-confirmed expectation}

\author{
Fábio Campos Tescari ${ }^{1}$ \\ Luiz Artur Ledur Brito ${ }^{1}$ \\ ${ }^{1}$ Fundação Getulio Vargas, Escola de Administração de \\ Empresas de São Paulo, São Paulo, Brazil
}

\begin{abstract}
Purpose-Despite its theoretical potential, the relational view proposed by Dyer and Singh (1998) has not been established as a dominant theoretical framework, since the concomitant use of its main constructs is rare. This paper intended to test the relational view considering the impact of its constructs on the economic value created in relationships between buyers and suppliers.
\end{abstract}

Design/methodology/approach - A cross-sectional survey with 121 respondents was conducted in the Brazilian chemical sector. To analyze the measurement models and test the hypotheses, confirmatory factor analysis and multiple linear regression were used.

Findings - The limited support for the hypotheses tested suggests that the operationalization of the relational view as an explanatory theory requires further study. Asset specificity seems to be the most solid construct, with a relevant effect on the relational value, and it is present in some moderating effects on environmental variables. The results also suggest that relational governance has some effect on the value captured by the supplier.

Originality/value - In addition to the need to review the operationalization of the Relational View, the proposed value measurement model contributed to identifying differences between the value created for the buyer and the value created for the supplier. The measurement scales of value creation presented good quality of fit and also represent a contribution for further research.

Keywords - relational view; value creation; buyer-supplier relationships.
461

Received on

$1 / 23 / 2017$

Approved on

$01 / 23 / 2018$

Responsible editor:

Prof. Dr. João Maurício Gama

Boaventura

\section{Evaluation process:}

Double Blind Review

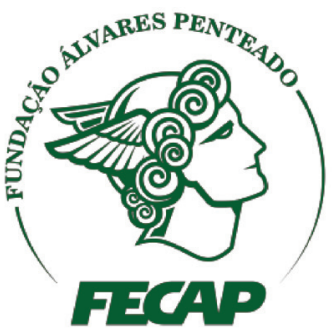

Review of Business

Management

DOI: $10.7819 /$ rbgn.v20i3.3541 


\section{Introduction}

The relational view, proposed in the seminal paper by Dyer and Singh (1998), is an important derivation of the resource-based view (RBV) (Acedo, Barroso, \& Galán, 2006). In the $\mathrm{RBV}$, the resources controlled by firms are the focus of analysis and are the source of performance heterogeneity and of competitive advantage itself. Because of this, a significant number of studies on supply chain management use the RBV combined with relational perspectives, especially those that focus on buyer-supplier relationships (Hitt, Xu, \& Carnes, 2016).

In turn, the relational view (RV) proposes that the resources that are found at the interface of the relationship between firms and that are created and shared can also have these effects. Given the emergence and increasing importance of the resource-based view, the relational view proposal was of great appeal to academics who study the relationship between firms and who, until then, had been restricted to other dominant theoretical approaches that focused on minimizing costs. The new theoretical view enabled this advance when it explained value creation (Zajac \& Olsen, 1993) and made a connection in this context between relationships and the competitive advantage of the firms involved in them (Kozlenkova, Samaha, \& Palmatier, 2014). Currently, the emphasis on value creation is also a consistent approach with the management of relational transactions embedded in the shared economy, which are not directly monetized. Value, therefore, becomes a relevant variable $v i s-\grave{a}$-vis the traditional performance-based approach.

One indication of the applicability of the relational view is the large number of articles citing the seminal article by Dyer and Singh. According to the Web of Science, there were 2,359 citations between 1998 and 2016, of which 286 were published in the last year. Among recent studies, some of the authors cite the article to indicate that relationships are sources of competitive advantage (Huemer, 2014; Li, Jiang, Pei, \& Jiang, 2017), while others cite it to highlight the generation of specific relationship assets (Zacharias, Nijssen, \& Stock, 2016) and to emphasize that collaborative relationships contribute towards minimizing transaction costs (Abdi \& Aulakh, 2017; Proch, Worthmann, \& Schlüchtermann, 2017).

Despite this apparent theoretical potential, however, the relational view has not yet been consolidated as a dominant theoretical framework and much of its initial empirical support, which was heavily based on the works of Jeffrey Dyer and his colleagues (Dyer, 1997; Dyer \& Hatch, 2006; Dyer \& Singh, 1998; Dyer, Singh, \& Kale, 2008), was not confirmed in later works, which ended up using variations of the initial theoretical structure. Considering the four constructs of the relational view, which are called relational resources, their concomitant use is rare. There are, however, some authors who use some of them (e.g., Chen, Preston, \& Xia, 2013), there are models that test some of them as antecedents (e.g., Hernández-Espallardo, Rodríguez-Orejuela, \& Sánchez-Pérez, 2010), and there are articles that operationalize constructs using different relational resource indicators (Liu, Luo, \& Liu, 2009; Narasimhan \& Nair, 2005), or that define specific relationships between the constructs (Hoetker \& Mellewigt, 2009). When Deboçã and Martins (2015) carried out their qualitative study, they found no evidence of relational view constructs in their analysis of inter-organizational relationships in two furniture centers.

In this article, we propose testing the relational view in its original theoretical structure, by analyzing the impact of the four relational resources on the economic value creation in relationships between buyers and suppliers. The model we used is an extension of the restricted concept of economic value created by a firm, as proposed by Brandenburger and Stuart (1996) and adopted as the basis for the current definition of competitive advantage in strategy (Adner \& Zemsky, 2006; Brito \& Brito, 2012; Peteraf \& Barney, 2003). It also allows us to evaluate the impact of relational resources on both sides of the 
dyad, since part of the value created is captured by the supplier, while another part is captured by the buyer. The study also makes contributions by introducing context variables that can moderate the effect of relational resources in an initiative to try and elucidate their lack of concomitance in empirically tested models. The intention, therefore, is to offer a contribution that will lead to more in-depth academic-scientific discussions about the relational view.

To meet the proposed objectives, a survey was conducted, with 121 responses being obtained from companies that supply chemical products and that have operations in Brazil. The multiple regression method was used to test the effect of the four relational resources (independent variables), the two context variables (uncertainty and competition), and the eight interactions between resources and context variables in value creation, which in turn was operationalized by way of three different dependent variables (value created for the supplier, value created for the buyer, and value coming from the relationship), with a regression for each dependent variable.

The structure of this article comprises four more sections besides this one. The theoretical section discusses value creation in relationships and the theoretical approaches used by studies into such relationships, besides presenting the proposed model and its hypotheses. The third section presents the methodological procedures used in the research, while the fourth gives the results and discusses them. The conclusions section deals with future challenges for the development of the relational view based on the results obtained, emphasizing the contributions made by the research and its limitations.

\section{Literature review}

This section discusses the broader scope of the relational view of strategy when analyzing value creation in relationships. We also present the theoretical foundations of the constructs that form the basis of the proposed model and the hypotheses constructed to analyze the relationship between relational view constructs (called relational resources) and value creation.

\section{I Theoretical approaches in relationship studies}

Transaction cost theory (TCE) and the relational view ( $R V$ ) are among the main theoretical perspectives used in interorganizational relationship studies (Burgess, Singh, \& Koroglu, 2006; Hitt, Xu, \& Carnes, 2016).

TCE emphasizes the search for efficiency that guides the expansion of a firm to the limit of acquiring a product or service in the market that it can produce or perform (Coase, 1937). In borderline situations, firms create governance mechanisms that lead to a configuration that results in lower transaction costs, which can range from market-oriented structures with no integration to full vertical integration (hierarchies). Between these extremes, hybrid, partial integration structures may be adopted by way of long-term contracts (Williamson, 2008).

Dyer and Singh (1998) are the key authors with writings on RV, which is an extension of the resource-based view (RBV). RBV considers that the competitive advantage of companies comes from their own attributes, called resources. For a firm to obtain competitive advantage the resources it has at its disposal must be valuable and rare and competitors must find them inimitable and non-substitutable (Barney \& Clark, 2007). Dyer and Singh (1998) took the view that peer companies or a network of companies may develop relationships that result in sustainable competitive advantage. Relationships between firms allow for the exploration of synergies and the development of activities that lead to relational rent being obtained. Relational rents are additional profits that a firm derives from a relationship, which might not be generated in isolation, and which are considered to be transaction value. The party with the rarest or scarcest resource in the relationship should capture more relational rents (Dyer \& Singh, 1998).

In short, TCE addresses the question of costs in quite a comprehensive manner, but 
from a unilateral perspective that ignores the interdependence between the firms involved in a relationship, as well as limiting adherence to interorganizational strategy issues (Zajac \& Olsen, 1993). RV is broader in scope and considers not only cost reduction but also the increase in customer willingness to pay as opportunities for creating superior value. There are, however, differences regarding the operationalization of RV constructs, since the use of models that simultaneously consider its four constructs is rare in the literature. Our proposal in this study was to test the four RV constructs separately as sources of value in a relationship, with the intention of contributing to the discussion about their parsimony and validity.

\subsection{Relational resources}

In their seminal article on the relational view, Dyer and Singh (1998) point out that the relationship between firms is a unit of analysis that is suitable for understanding the competitive advantage that accrues from obtaining relational rents. Relationships with other firms, combined with own resources, bring greater rents than the individual result. In this approach, the authors identify four interorganizational resources (relational resources) that are sources of these relational rents: relation-specific assets, knowledge sharing routines, complementary resources, and relational governance. These resources are examined in detail and the authors identify isolated subprocesses and mechanisms for preserving relational rents.

Asset-specificity comes from investments that are exclusively ear-marked for the partner in a relationship, with the expectation of obtaining mutual benefits and the development of competences that depend on the duration of the safeguards and the volume of transactions (Dyer and Singh, 1998; Kang, Mahoney, \& Tan, 2009; Mesquita, Anand, \& Brush, 2008). Knowledge sharing presupposes a constant and open flow of communication between partners, and is considered critical for interorganizational learning to succeed. Additional rents may be obtained by intensifying exchanges of knowledge about individual routines, which generates ideas and information that lead to higher levels of technological performance and innovation (Dyer \& Singh, 1998; Kale, Singh, \& Perlmutter, 2000).

By reducing transaction costs for the buyer and protecting the supplier's access to shared resources, resource complementarity enables partners to promote a synergistic combination of resources that have positive results on the relationship (Dyer \& Singh, 1998; Lin, Yang, \& Arya, 2009). Finally, the central idea of relational governance is to develop mechanisms that reduce transaction costs by restricting opportunism (Dyer \& Chu, 2003; Dyer \& Singh, 1998). The efficiency of governance measures in reducing costs and mitigating opportunistic behavior increases the value created in a relationship and, under balanced power conditions, the parties also capture value.

\subsection{Value-creation in relationships}

The generation of mutual benefits when buyer-supplier relationships are being developed constitutes a differential for the parties and can be understood as part of the value created in the relationship, which becomes a competitive advantage for firms (Kozlenkova, Samaha, \& Palmatier, 2014; Peteraf \& Barney, 2003). This is why the benefits resulting from buyer-supplier relationships became a source of interest for researchers.

Various studies have shown that continuing relationships between firms lead to superior performance (for example, Centenaro \& Laimer, 2017; Kozlenkova, Samaha, \& Palmatier, 2014; Liu et al., 2009). The use of performance measures, however, is incomplete, since they address only one of the perspectives of the relationship. Any analysis, therefore, should also consider the gains obtained from the partnerships that exist between buyers and suppliers (Lindgreen \& Wynstra, 2005). The value concept can represent this integrative dimension of the generation and 
capture of those benefits that lead to competitive advantage, but only a few recent studies have adopted this view (Chatain, 2011; Kim \& Choi, 2015; Miguel, Brito, Fernandes, Tescari, \& Martins, 2014; Tescari \& Brito, 2016).

The operationalization of the measurement of value used in this study enables us to identify those parts of total value created in a relationship that are captured by the parties individually, based on the concept of economic value created, as proposed by Brandenburger and Stuart (1996). In their model, the value created by a company is the wedge between the buyer's willingness to pay and the opportunity cost of the supplier, according to Figure 1. The total value created is subsequently distributed between the participants of the respective supply chain, which refers to the concept of value capture by the parties.

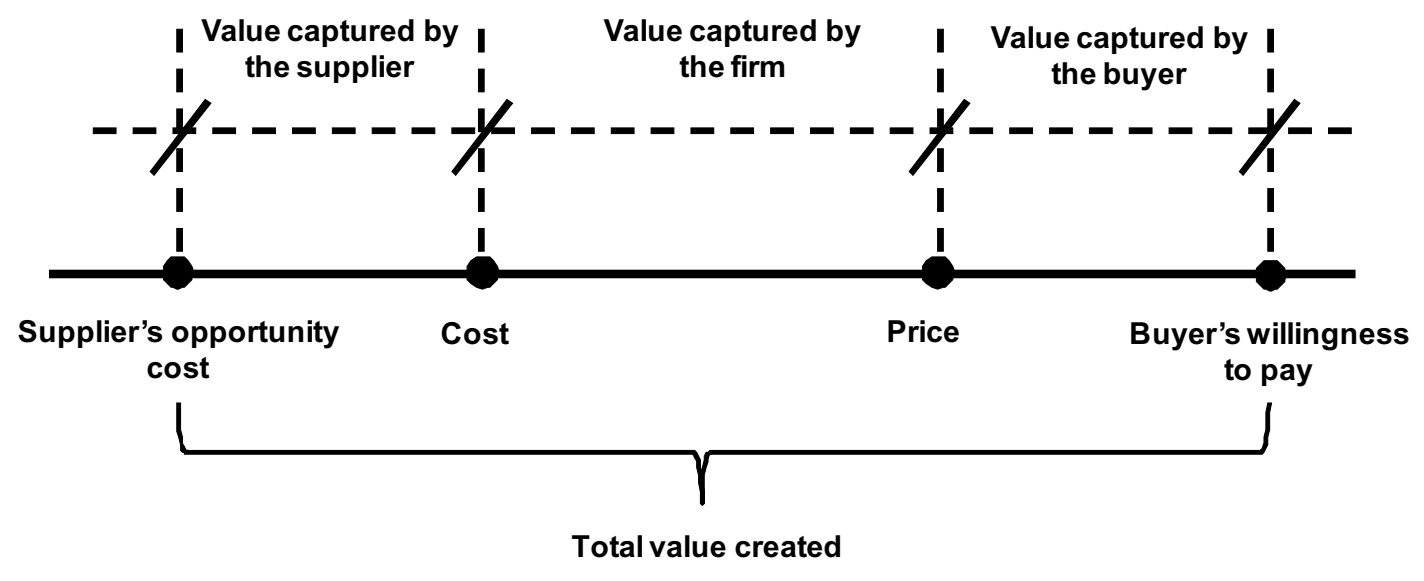

Figure 1. Value created by a focal company.

Source: Adapted from Brandenburger \& Stuart (1996).

The wedge between price and cost is that portion of value that is directly captured by the focal company. The wedge between willingness to pay and price is what regulates the possibility of making the purchase and represents the fraction of the total value created that is captured by the buyer. Willingness to pay represents an estimate of the sum of benefits perceived by the buyer and is always likely to exceed the price at which the transaction is carried out. The greater the willingness to pay in relation to the price suggested by the supplier, the greater the value captured by the buyer.

In turn, the supplier captures the wedge between the economic cost incurred by the focal company and the supplier's opportunity cost, in other words, its best selling option other than to the focal company. This option is an alternative for selling the product or service that represents the minimum price the supplier considers acceptable, considering the other possibilities that exist for offloading the product (Shavit, Rosenboim, \& Malul, 2011). The value created, therefore, shows the heterogeneity of the demand and the preferences and evaluations of the actors involved, while value capture results from the opportunities for increasing rents on both sides of the relationship (Priem, Li, \& Carr, 2012).

Figure 2 schematically illustrates the application of this model to a buyer-supplier dyad (Miguel et al., 2014). The value that remains with the buyer in this relationship is the difference between its willingness to pay $\left(W P_{s}\right)$ and the price actually paid $(P)$. This portion (indicated by $\mathrm{A}$ ) represents the value created by the supplier that is assigned to the buyer in the context of the dyad. In this paper, this portion is called value created for the buyer (VCB). Similarly, the portion indicated 
by $B$ represents that part of the value created by the buyer that is assigned to the supplier. It results from the difference between the price charged by the supplier and its opportunity cost $\left(O C_{b}\right)$.
Portion B is called value created for the supplier (VCS). The integration of the two elements (sum of $A$ and $B$ ), therefore, represents the total value created in the dyad.

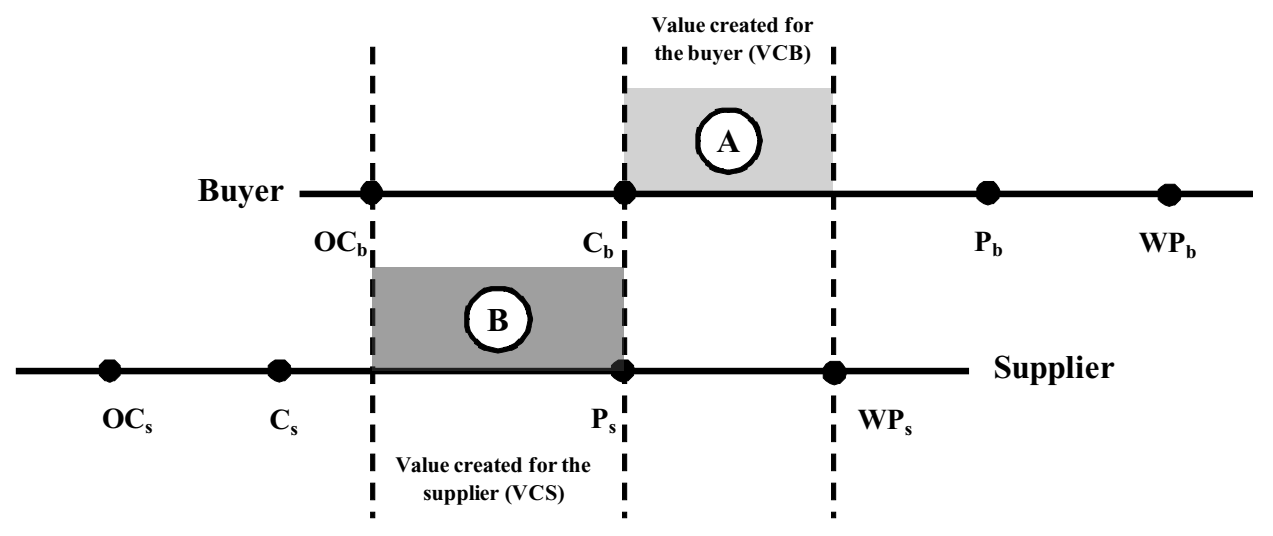

Figure 2. Value created in the dyad.

During a relationship, companies can dedicate themselves to joint or individual activities that modify the total value created, thereby increasing the buyer's willingness to pay or reducing the supplier's opportunity cost. Tanskanen and Aminoff (2015) classified the nature of these activities into economic-based, behavior-based, resource-based, and bridgingbased. Their intensity can determine how the value created will be transferred to the parties in the form of benefits that contribute to improving their performance. This phenomenon is represented by the dashed lines in Figure 2 being displaced over time.

The origin of the value that is transferred may be a characteristic or original resource of one of the parties that is independent of the relationship itself, and generally derives from previous events (Kang, Mahoney, \& Tan, 2009; Mesquita, Anand, \& Brush, 2008). On the other hand, part of the value comes over the time the relationship lasts and indicates the evolution of the buyer-supplier relationship, which ends up transcending the simple exchange of goods (Kumar, Banerjee, Meena, \& Ganguly, 2016; Rezende, Lima, \& Versiani, 2012). The benefits generated are the result of the synergies identified by the parties that lead to the efforts they make to stay in the relationship (Mena, Humphries, \& Choi, 2013). In this paper, this incremental value was called value coming from the relationship (VCR). It ends up being destined for one or for both parties and is incorporated into the VCB or VCF.

There are different levels of investment in a relationship depending on the relative size of the supplier compared with the buyer, with benefits being proportionally captured by the parties. In other words, the share of value coming from the relationship is added to the benefits derived from the intrinsic resources of the parties, which are among the previously known factors that motivated the buyer to select the supplier, or vice versa (Castellucci \& Ertug, 2010; Pulles, Schiele, Veldman, \& Hüttinger, 2016). From a different perspective, the value coming from a relationship (VCR) can be broken down into parts that represent the origin of the benefits, which may have been generated by the firms prior to the relationship, or are exclusive to the relationship, and in this case they usually increase as the relationship evolves. 


\subsection{Context variables}

One of the reasons that may have led to the four relational resources barely being used in combination in empirical models is the influence of context variables. In this study, therefore, two variables were introduced to complement the proposed investigation: uncertainty and degree of competition. Uncertainty is one of the most widely used measures in the literature of the impacts of the external environment and is one of the key dimensions in the study of relationships (Ambrose, Marshall, \& Lynch, 2010; Palmatier, Dant, \& Grewal, 2007). Most of the published papers deal with the impact of uncertainty on issues that are more directly linked to manufacturing and quality, while others use models that test the impact of uncertainty on interorganizational relationships, such as, for example, the formation of cooperation networks (Balestrin \& Arbage, 2007), opportunism in outsourced service relationships (Handley \& Benton, 2012), and the relationship between supply chain integration and operational performance (Wong, Boon-Itt, \& Wong, 2011).

There are many understandings of the concept of uncertainty, and in this study we adopted an approach that describes the individual's perception of the predictability of the environment, called state uncertainty (Milliken, 1987), from the perspective of the supplier in relation to the business environment.

The second context variable addresses the competition environment. Competition occurs when the various actions and reactions of competitors lead to a reduction in current profits (Fouskas \& Drossos, 2010). Its choice is related to the sector the research covered, the chemical industry, which is a very competitive market, and which demands innovation that makes it possible for individual gains and positive points of reference vis-à-vis competitors to be maximized, or in other words, for competitive advantage to be obtained (Leite, Lopes, \& Silva, 2009). Competition in the dyad is more evident on the supplier side, since different companies generally compete for a single decision that is made by the buyer. Because of this, the context variable used will be the degree of competition in the supplier market.

\subsection{Proposed model and hypotheses}

$\mathrm{RV}$ defines four relational resources, which are sources of relational rents: relationspecific assets, knowledge sharing routines, complementary resources, and relational governance (Dyer \& Singh, 1998). It is expected, therefore, that the greater the relational resources, the greater the value creation. Analysis of the model studied in this paper did not enable us to establish the discriminant validity between knowledge sharing and resource complementarity. These two constructs, therefore, were merged into a construct defined as relationship practices. For clarity, it should be mentioned that the hypotheses were constructed for this new construct. Also for clarity, we must stress that the measurement of the value creation variable considers three portions, as discussed in Section 2.3: value created for the supplier, value created for the buyer, and value coming from the relationship.

The complete research model is shown in Figure 3. Each of the three RV constructs (relation-specific assets, relational governance, and relationship practices) was an independent variable in the analysis. The dependent variable is value creation. Because of its three parts, the analysis was carried out three times to investigate the effect of relational resources on each element of value created. The model also considers two context variables (state uncertainty and degree of competition in the supplier market) and six interactions between the relational resources and the context variables in each dependent variable. The hypotheses of the study are shown below. 


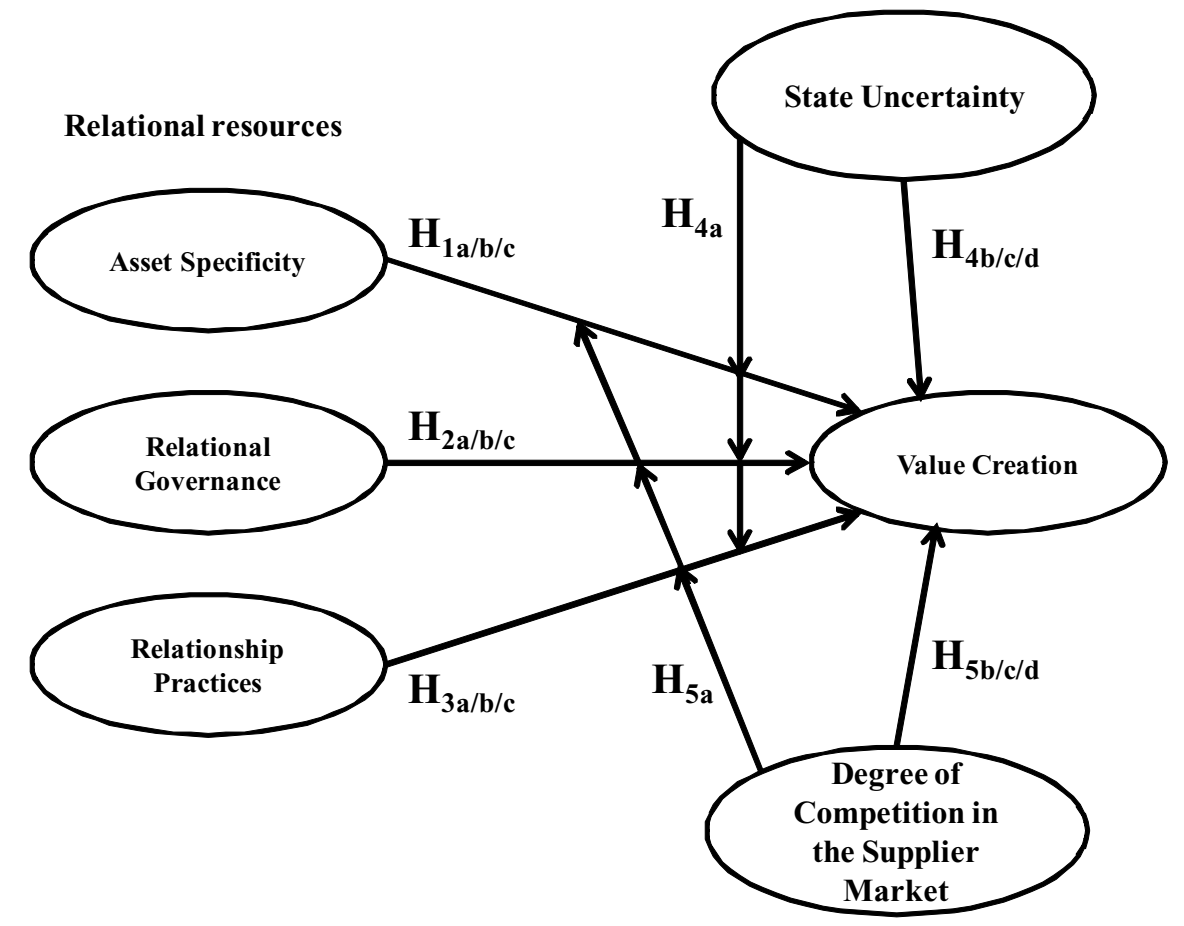

Figure 3. Complete research model.

The first hypothesis refers to asset specificity, which occurs through investments that are exclusively ear-marked for a business partner and leads to the creation of value because of cost reduction, product differentiation, a reduction in defect rates, and shorter new product development cycles. In the context of investments in specific assets, supply duration, usually via contracts, reduces buyer opportunism and can guarantee an adequate return on investment, assuming that the relationship continues (Dyer \& Singh, 1998). Since the measurement model considers three types of value, both Hypothesis 1 and the others will address these three relationships, indicated by letters, where " $a$ " refers to the value created for the buyer (VCB), "b" refers to the value created for the supplier (VCS), and " $\mathrm{c}$ " to the value coming from the relationship (VCR). The first hypothesis, therefore, can be formulated:

Hypothesis 1a/1b/1c: Asset specificity has a positive influence on value creation.

Relational governance is guided by the search for a structure and mechanisms that minimize transaction costs, leading firms to adopt initiatives that result in value creation, such as investments in specific assets, knowledge sharing, and resource complementarity (Dyer $\&$ Singh, 1998). Based on the expectation that a relationship can generate gains, the parties establish mutual agreements. Generally, such agreements initially contain formal safeguards that require financial commitment. As the relationship evolves, transaction costs are reduced, since contract drafting, monitoring, and renewal costs are avoided, while formal safeguards are replaced by informal ones, such as trust and restrictions on the use of power, in the form of coordination mechanisms (Dyer \& Singh, 1998). Therefore, in relation to governance, the second hypothesis is proposed:

Hypothesis 2a/2b/2c: Relational governance has a positive influence on value creation.

Knowledge sharing is an informal and continuous process of communication between companies, which enables efforts to be directed 
towards reducing costs and improving the operational and financial performance of the whole chain, in the search for an ideal balance of functions that leads to gains that can be captured by the parties (Cao \& Zhang, 2011; Dyer \& Singh, 1998). The generation of relational rents from knowledge sharing routines occurs due to (i) the absorptive capacity, which is the ability to recognize value and to assimilate and apply the information received (Cohen \& Levinthal, 1990), and (ii) the encouragement to be transparent, which incentivizes the transfer of knowledge (Dyer \& Singh, 1998).

The complementary nature of resources presupposes that the resources that derive from a relationship between parties cannot be obtained in the market, and that their combination results in a synergistic effect that allows them to benefit from the positive impacts they have on performance due to the reduction in transaction costs (Dyer \& Singh, 1998; Lin, Yang, \& Arya, 2009). In this view, the concept of complementarity is expanded by including the requirements of compatibility between companies that allow for better use to be made of the synergies identified, in addition to creating specific mechanisms for accessing shared resources that hinder the entry of competitors and accelerate knowledge exchange for the greater mutual exploration of business potential (Pereira \& Pedrozo, 2005). Considering that, although conceptually different, knowledge sharing and resource complementarity did not show discriminant validity, at least empirically, and that the two concepts were integrated into what we called relationship practices, we propose:

\section{Hypothesis 3a/3b/3c: Relationship practices have a positive influence on value creation.}

An environment of uncertainty is characterized by the difficulty of accessing information and predicting changes. Different risks in the supply chain can lead to uncertainty for both supply and demand, such as: sudden supply interruptions, losses, failures in the procurement process, and inaccuracies in forecasting demand (Speier, Whipple, Closs, \& Voss, 2011). Scenario changes lead to increases in transaction costs and risks of losing competitiveness, which encourages companies to seek a greater degree of integration that helps improve their performance and, as a consequence, leads to an increase in their competitive advantage via the creation of value that is superior to that of their competitors (Cheung et al., 2010; Shervani, Frazier, \& Challagalla, 2007). The fourth hypothesis derives from this:

\section{Hypothesis 4a: State uncertainty positively moderates the relationship between relational resources and value creation.}

The study also checked the direct effect of state uncertainty on value creation. Hult, Ketchen, and Arrfelt (2007) proved that, in spite of uncertainty increasing the propensity to expand knowledge between parties, it has a negative influence on the relationship between buyer satisfaction and operational performance, resulting in lower value capture by the supplier to the extent that its market share varies.

On the other hand, buyers tend to reduce their willingness to pay with a view to reducing the risks associated with unpredictability in an environment of high uncertainty, since this limits the buyer's ability to assess possible supply risks that may arise from the relationship itself (for example, a reduced use of formal contracts, the definition of responsibilities, or information sharing between parties), or market aspects of the analyzed industry that lead to changes in the sales profile over time (Hoffmann, Schiele, \& Krabbendam, 2013; Jayaraman, Narayanan, Luo, \& Swaminathan, 2013). Similarly, but from an inverse viewpoint, Amit and Zott (2001) comment that the creation of value derives from a reduction in uncertainty, because, if there is less uncertainty, greater efficiency can be obtained in the transactions. 
Therefore, we formulate the following hypothesis:

Hypothesis 4b/4c/4d: State uncertainty has a negative influence on value creation.

With regard to the competition environment, since buyers tend to act opportunistically when they have several sources of supply by limiting the number of transactions with a single supplier, it is expected that the degree of competition in the supplier market negatively affects the relationship between relational resources and value creation. The resulting hypothesis is:

Hypothesis 5a: The degree of competition in the supplier market negatively moderates the relationship between relational resources and value creation.

In highly competitive markets, suppliers tend to reduce their opportunity cost in order to increase sales, which allows them to better manage a lasting and sustainable competitive advantage (O'Cass \& Weerawardena, 2010). Since the buyer acknowledges the supplier's efforts in the form of relationship continuity, we expect this buyer to have taken its decision considering the benefits that can be generated by this transaction. Therefore:

Hypothesis 5b/5c/5d: The degree of competition in the supplier market has a positive influence on value creation.

\section{Method}

We carried out a cross-sectional survey with companies in the Brazilian chemical industry, which we chose because of its great potential for developing long-lasting relationships. The technical nature of the products requires a greater approximation between suppliers and buyers, in order to explore different customization possibilities (Galembeck et al., 2007). The chemical industry is also characterized by substantial investments in research and development, in its search for technological innovations that enable companies to keep up with the rapid advances in market demands while being able to offer multiple application solutions for portfolio products (Brito, Brito, \& Morganti, 2009).

In this context, company engagement in relationship-building is a source of value creation in the chemical industry, since intangible assets are widely used as a way of providing agile and timely responses to customer demands, such as knowledge sharing, patent registration, and the adoption of innovation (Baltagi, Egger, \& Kesina, 2016; Moori, Shibao, \& Kimura, 2016). However, opportunistic behaviors, which are generated by a scenario in which there is margins compression, may weaken the intensity of relationships in the chemical industry (Cheung, Myers, \& Mentzer, 2011).

The methodological aspects of the study will be detailed below. First, in the data collection section we shall address the way in which we selected the companies that went on to make up the sample. The following section details the construction of the measuring instrument, which included the development of scales and methodological procedures for defining the final version of the new scales and the scales obtained from the literature. Finally, we describe the steps we used in analyzing the data.

\section{I Data collection}

The research outline focused on the relationship of a supplier with a specific buyer at the business unit level. Questionnaires were sent to those responsible for commercial service (sales), so as to reflect the strategies of the organizations they represent. Each response refers to a dyadic relationship, based on information about a specific buyer that was defined by the respondents at the time they completed the questionnaire. Despite applying the survey instrument exclusively to suppliers, it reflects the perspectives of the buyersupplier relationship, which therefore constitutes the study's unit of analysis (Chen \& Paulraj, 2004). 
The list of company contacts was obtained from the Brazilian Chemical Industry Association (ABIQUIM) and featured a total of 735 chemical companies operating in Brazil. There was a prior contact with the companies phase, when we sought information about potential respondents (name, phone number, and email), our aim being to minimize the possibility of questionnaires being lost or completed by someone who was not qualified to do so (Forza, 2002). We sent a total of 445 questionnaires to those responsible for commercial service, who had been identified in the previous contact phase. One hundred and twenty-one responses were considered valid and complete; in other words, there was a response rate of $27 \%$.

\subsection{Measurement instrument}

In order to preliminarily check the content validity of the constructs, when we developed the survey instrument and the measurement scales we included an extensive search of the existing literature and undertook a Q-Sort (Nahm, Rao, Solis-Galvan, \& Ragu-Nathan, 2002). The Q-Sort was carried out in two rounds, using five judges, three of whom were academics and two of whom were executives from the chemical industry. Since multiple judges and analyses are an important factor for the reliability of the process, we used different methods for analyzing the judges' evaluations: the convergence index between individual responses, a quantitative assessment by calculating the Kappa Index, the convergence index per construct (analysis of the percentage of judges who agreed with the theory), and a comparison between the allocation of the constructs. The analyses indicated the items that should be re-examined and, in cases of inadequate or ambiguous completion, items were eliminated (Nahm et al., 2002). Although a pretest is an important measure of the reliability of the research, the use of Q-Sort confers reliability and validity to the research instrument (Santos \& Amaral, 2004).

This study was based on the operational methodology adopted by Miguel et al. (2014) for defining the scales used for measuring value. These authors separately assessed the value created for the buyer and the value created for the supplier considering willingness to pay and opportunity cost separately. In the model we used in this study, the two concepts were combined into a single scale that considers the value resulting from the relationship.

With the exception of the scales used for measuring value creation, which we devised and tested for this study, the choice of the others sought to favor scales that had been previously validated in the literature and that had satisfactory reliability indices. We also analyzed those items that best fit the constitutive definition of the constructs, where we concentrated on reflexive scales that enable convergent validity to be better checked (Edwards \& Bagozzi, 2000). The various indicators of each construct were measured using seven-point Likert scales. Although the formatting of items with Likert-type gradations is essentially ordinal, the use of summated scales, as is the case with this research, can be considered to be interval (Carifio \& Perla, 2008; Norman, 2010). Back translation (English-Portuguese-English) was carried out to identify discrepancies and to adjust the wording of the survey instrument (Flynn, Huo, \& Zhao, 2010).

\section{$3 \cdot 3$ Data analysis}

The data analysis included three steps. In the first, we carried out a basic descriptive statistical analysis, after which we validated the scales used, based on confirmatory factor analysis, considering unidimensionality, discriminant and convergent validity, and scale reliability. The third step analyzed the relationships between the constructs and checked the hypotheses we formulated, including direct relationships and moderation, using the multiple regression technique. We used several statistical tools (in particular, confirmatory factor analysis and multiple linear regression) from the SPSS and Amos 22 software to analyze the measurement models and test the hypotheses. 


\section{Results}

The results section gives the descriptive statistics of the data we collected, the unidimensionality tests, discriminant and convergent validity, scale reliability, and the hypothesized relationship tests. In general, the scales were validated and could be used to test the model, giving limited support for the hypotheses we formulated.

\section{I Descriptive statistics}

Our analysis of missing data indicated that there was no pattern and these occurrences were rare, thus being characterized as "missing completely at random". Therefore, we estimated the missing data by taking the average of the responses of the respective indicator (McDonald $\&$ Ho, 2002). The descriptive statistics proved to be adequate. The averages of the items used to measure value and relational resources ranged from 4.37 to 6.23 on a scale of 1 to 7 . To assess the impact resulting from the way the data were distributed we assessed univariate normality by analyzing the skewness and kurtosis coefficients, while the multivariate normality test was based on Mahalanobis distances (Kline, 2005). The results indicated that the deviations from normality were small and acceptable, thus allowing for the use of $\mathrm{F}$ and $\mathrm{t}$ statistics for the data analysis, which included confirmatory factor analysis and multiple regression (Hair et al., 2009).

We assessed non-response bias by comparing the responses of the initial and final dispatch of questionnaires and found no relevant evidence that there had been any bias (Armstrong \& Overton, 1977). The bias test for descriptor variables also indicated no significant results. The variables we analyzed were: the supplier's average annual gross sales; the relative size of the companies; the percentage the buyer represented of the supplier's total sales; the degree of product standardization; and product type. The respondents came predominantly from companies whose average annual sales were over BRL 300 million. Compared to the buying company, there was a certain balance in the relative size of the suppliers, with 58 buying companies being larger than the supplier, while 43 suppliers were larger than their customers. The sample consisted mainly of managers, salespeople, and key account managers, who had had a relationship with the chosen buyer for between 2 and 5 years. Table 1 shows the demographic profile of the sample.

Table 1

\section{Demographic profile of the sample}

\begin{tabular}{|c|c|c|}
\hline Average annual sales & Number of respondents & Percentage \\
\hline Less than $\mathrm{R} \$ 2.4$ million & 4 & $3.4 \%$ \\
\hline From $\mathrm{R} \$ 2.4$ million to $\mathrm{R} \$ 16$ millions & 10 & $8.4 \%$ \\
\hline From $\mathrm{R} \$ 16$ million to $\mathrm{R} \$ 90$ million & 19 & $16.0 \%$ \\
\hline From $\mathrm{R} \$ 90$ million to $\mathrm{R} \$ 300$ million & 17 & $14.3 \%$ \\
\hline More than $\mathrm{R} \$ 300$ million & 69 & $58.0 \%$ \\
\hline Buyer size compared with supplier & Number of respondents & Percentage \\
\hline Much smaller & 18 & $15.0 \%$ \\
\hline Smaller & 25 & $20.8 \%$ \\
\hline Same size & 19 & $15.8 \%$ \\
\hline Bigger & 24 & $20.0 \%$ \\
\hline Much bigger & 34 & $28.3 \%$ \\
\hline Position of respondent in the firm & Number of respondents & Percentage \\
\hline CEO or Deputy CEO & 4 & $3.4 \%$ \\
\hline Director & 20 & $16.8 \%$ \\
\hline Manager & 56 & $47.1 \%$ \\
\hline Coordinator / Supervisor & 14 & $11.8 \%$ \\
\hline Salesperson / Key account manager & 27 & $22.7 \%$ \\
\hline
\end{tabular}




\subsection{Confirmatory factor analysis}

We checked the dimensionality, validity, and reliability of the measurement of the constructs by way of confirmatory factor analysis (CFA), using the Amos software. This software, whose method is based on covariance, is more suitable for confirmatory factor analysis since it includes error analysis and the samples are of adequate size for the distribution of the constructs used (Peng \& Lai, 2012).

However, since the size of the sample affects the model and the theoretical development of the covariance analysis starts from solutions that use large samples, we chose to carry out CFA separately for the different constructs (Brown, 2006; Chen \& Paulraj, 2004). In adopting this approach, we tried to obtain models that were better adjusted for the subsequent testing of the hypotheses. We analyzed three measurement models separately: relational resources, value creation, and context variables, so that factor analysis could confirm, in each model and for the sample we collected for the study, the interrelationships of the constructs that were defined using consolidated theoretical sources as a basis (Jöreskog, 1993).

We eliminated some indicators after a substantive analysis of their importance, but preserved the fundamental idea of the construct, based on an analysis of the modification indices calculated by Amos, which reflect the possible impact of the freely estimated parameters on the $\chi^{2}$ of the model being analyzed (Brown, 2006). After this adjustment process, the measurement scales of the constructs resulted in between three and five indicators, which is in accordance with what is recommended (Hair et al., 2009). Table 2 offers a comparison between the number of variables of the theoretical model after the confirmatory factor analysis.

Table 2

\section{Comparison of the number of variables of the model}

\begin{tabular}{lcc}
\hline \multirow{2}{*}{ Factors } & \multicolumn{2}{c}{ Items } \\
\cline { 2 - 3 } & Initial CFA & Final CFA \\
\hline Value created for the supplier (VCS) & 5 & 4 \\
Value created for the buyer (VCB) & 5 & 3 \\
Value coming from the relationship (VCR) & 3 & 3 \\
Asset specificity (AS) & 4 & - \\
Knowledge sharing (KS) & 4 & - \\
Resource complementarity (RC) & 6 & 5 \\
Relationship practices (RP) & - & 3 \\
Relational governance (RG) & 5 & 3 \\
State uncertainty (SU) & 4 & 4 \\
Degree of competition in the market (DCM) & 4 & \\
\hline
\end{tabular}

Following the Fornell and Larcker (1981) test, the original relational resources measurement model did not have discriminant validity between two constructs, when comparing the nested model (the correlation between constructs is equal to 1 ) and the model where the correlation between the constructs is free (Anderson \& Gerbing, 1988). We therefore defined a new construct called Relationship Practices, based on the association of the Knowledge Sharing and 
Resource Complementarity constructs. Table 3 shows the fit indices of the three measurement models we tested, where the general analysis shows good fit indices. Table 4 , in turn, shows the correlation matrix.

Table 3

\section{Fit indices of the measurement models analyzed}

\begin{tabular}{lccccc}
\hline Index & Relational resources & Value & Context variables & Recommended value & Reference \\
\hline CMIN/DF & 1.191 & 1.334 & 0.624 & Less than 2 & Kline, 2005 \\
value-p of $\chi^{2}$ & 0.187 & 0.098 & 0.836 & More than 0.05 & Kline, 2005 \\
GFI & 0.937 & 0.941 & 0.981 & More than 0.9 & Bentler \& Bonnett, 1980 \\
NFI & 0.891 & 0.918 & 0.953 & More than 0.9 & Bentler \& Bonnett, 1980 \\
CFI & 0.980 & 0.978 & 1.000 & More than 0.9 & Kline, 2005 \\
RMSEA & 0.040 & 0.053 & 0.000 & Less than 0.05 & Kline, 2005 \\
RMR & 0.099 & 0.102 & 0.080 & Less than 0.10 & Kline, 2005 \\
\hline
\end{tabular}

Table 4

\section{Correlation matrix}

\begin{tabular}{lllllllll}
\hline & VCS & VCB & VCR & AS & RP & RG & SU & DCM \\
\hline VCS & 1.00 & & & & & & & \\
VCB & 0.26 & 1.00 & & & & & & \\
VCR & 0.07 & 0.29 & 1.00 & & & & & \\
AS & 0.09 & 0.20 & 0.28 & 1.00 & & & & \\
RP & 0.08 & 0.27 & 0.22 & 0.30 & 1.00 & & & \\
RG & 0.14 & 0.23 & 0.17 & 0.39 & 0.54 & 1.00 & & \\
SU & -0.01 & -0.26 & -0.07 & 0.08 & -0.09 & -0.13 & 1.00 & \\
GCM & 0.08 & -0.07 & 0.14 & 0.11 & 0.02 & 0.19 & -0.02 & 1.00 \\
\hline
\end{tabular}

We assessed the reliability of the constructs by calculating the composite reliability index $\left(\rho_{c}\right)$. In turn, average variance extracted (AVE) analysis was used to evaluate the convergent validity of the constructs. The indicators of both analyses are shown in Table 5. The composite reliability index exceeds the reference value of 0.70 , with the exception of the case of state uncertainty, whose value is close to this figure, indicating a satisfactory level of construct reliability (Fornell \& Larcker, 1981). In relation to convergent validity, the results of average variance extracted are lower than the recommended value $(0.50)$ for three constructs, but because of internal consistency and the fact that its indicators were obtained from the literature, the convergent validity can be considered satisfactory (Fornell \& Larcker, 1981). This is one of the limitations of the study. The fact we are measuring the variables with a large error may explain why it was not possible to find a relationship between them, for which reason we indicate the need to carry out other studies to improve the proposed scales. 
Table 5

Reliability and the convergent validity of the constructs

\begin{tabular}{lcc}
\hline Construct & $\begin{array}{c}\text { Composite reliability } \\
\left(\rho_{c}\right)\end{array}$ & $\begin{array}{c}\text { Average variance extracted } \\
\text { (AVE) }\end{array}$ \\
\hline Value created for the supplier & 0.83 & 0.55 \\
Value created for the buyer & 0.84 & 0.64 \\
Value coming from the relationship & 0.83 & 0.63 \\
Asset specificity & 0.77 & 0.54 \\
Relationship practices & 0.79 & 0.43 \\
Relational governance & 0.75 & 0.50 \\
State uncertainty & 0.66 & 0.40 \\
Degree of competition in the market & 0.75 & 0.44 \\
\hline
\end{tabular}

\subsection{Common method variance}

Regarding the common method variance, we followed some recommendations in developing the questionnaire to mitigate its effects, such as, for example, the random presentation of indicators, the use of different scales and sections for evaluating dependent and independent variables, and the guarantee of response confidentiality (Podsakoff, Mackenzie, Lee, \& Podsakoff, 2003). The Harman factor test was also applied, whose results suggest that the validity of the data related to common variance was not affected (Podsakoff \& Organ, 1986). These results indicate that the measurements of the constructs are valid and reliable. We then created summated variables for each construct, which were used in subsequent analyses.

\subsection{Results of the hypothesis tests}

The hypothesized relationship tests were based on the multiple regression method, which tested the effect of the relational resources, the context variables, and the interactions between the relational resources and context variables (all these being independent variables) on the value variables (dependent variables). As we used three different dependent variables, multiple regression was performed three times.

Since the tested models foresee interactions, two steps were taken. First, the variables were centered on their averages and thus the interaction variables were obtained from the product of these centered variables. This procedure mitigates the high multicollinearity that may exist between the independent variables and the interactions, as well as between the interactions. The second procedure was to add the independent variables and the interactions to the model separately in a hierarchical regression, which enables the effects of moderation to be assessed after eliminating the linear effects of the other variables (Tang $\&$ Rai, 2012).

We included two control variables in the regression: the length of time of the relationship between companies, as this can reduce the influence of the learning curve and the benefits associated with long-term relationships (Kang, Mahoney, \& Tan, 2009); and the size of the respondent company based on its sales, which can interfere with its competitiveness, due to greater access to resources (Hult et al., 2007; Mesquita et al., 2008).

The final results of the multiple regression analysis, with an indication of the standardized coefficients and the tests of the formulated hypotheses, are shown in Table 6. Support for the hypotheses that propose that relational resources have a positive effect on value was generally very limited.

In the regression that had as its dependent variable the value created for the buyer (VCB), none of the relational resources had a significant effect, despite the regression coefficients being 
positive, thus not supporting hypotheses $\mathrm{H} 1 \mathrm{a}$, $\mathrm{H} 2 \mathrm{a}$, and $\mathrm{H} 3 \mathrm{a}$. The moderation effects of state uncertainty on the relational constructs were also not significant and did not support hypothesis H4a. The direct effect of state uncertainty on the value created for the buyer was negative and significant, thus supporting hypothesis H4b. The presence of uncertainty reduces the perception of benefits because of their unpredictability. The effects of the degree of competition and its interactions were not significant and did not support hypotheses $\mathrm{H} 5 \mathrm{a}$ and $\mathrm{H} 5 \mathrm{~b}$.

Table 6

Results of the multiple regressions for value creation

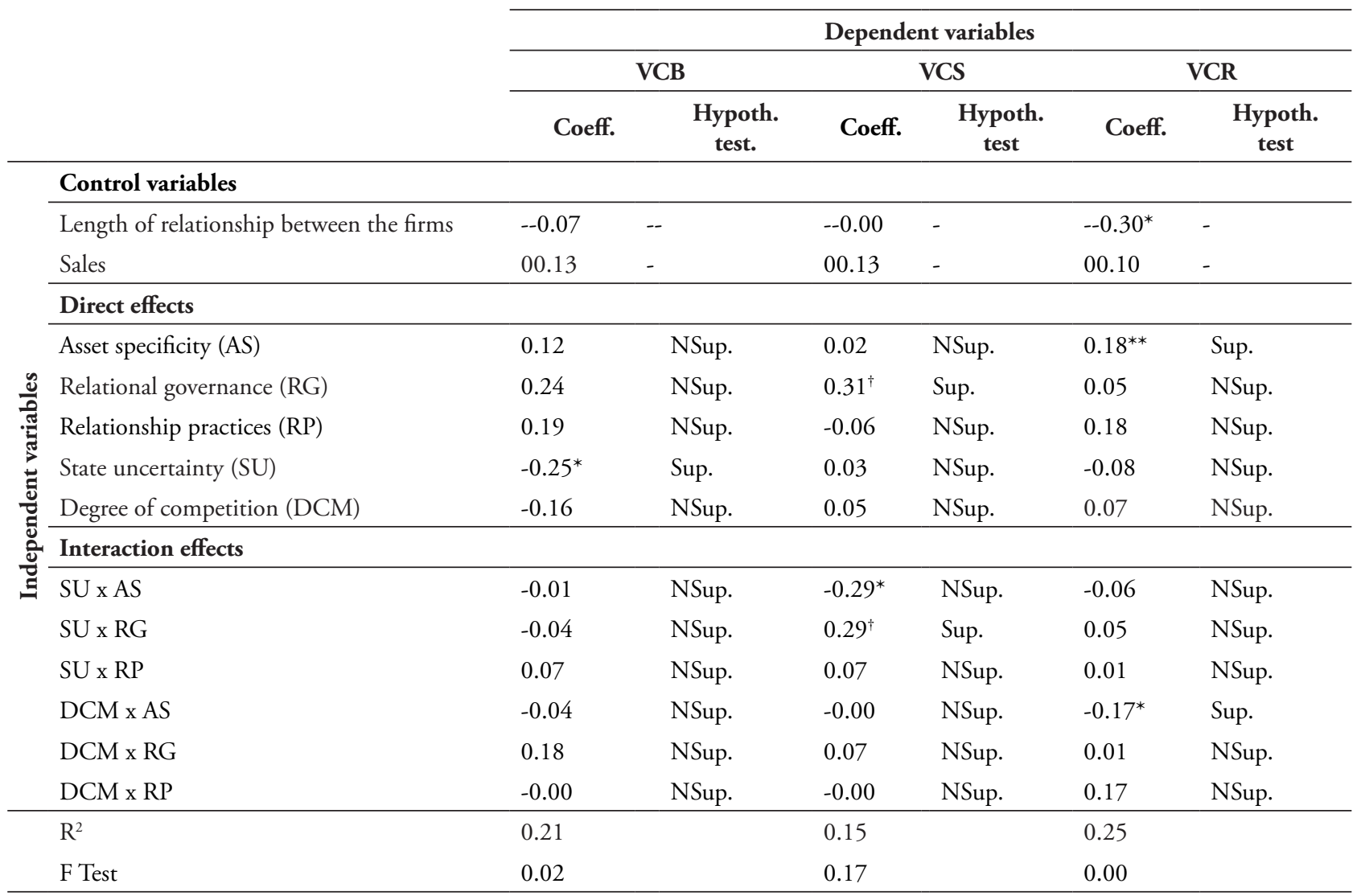

Note. ${ }^{*} \mathrm{p}<0.01 ;{ }^{* *} \mathrm{p}<0.05 ; \dagger \mathrm{p}<0.10$; Sup.: Hypothesis supported; NSup.: Hypothesis not supported.

In the regression whose dependent variable was the value created for the supplier (VCS), only relational governance had a marginally significant coefficient $(\mathrm{p}<0.10)$, while the other relational resources had no significant effects. Hypothesis $\mathrm{H} 2 \mathrm{~b}$ was partially supported, although no support was found for hypotheses $\mathrm{H} 1 \mathrm{~b}$ and H3b. State uncertainty had a significant moderating effect on asset specificity $(\mathrm{p}<0.01)$ and relational governance $(\mathrm{p}<0.10)$, thus offering partial support for hypothesis H4a. The effect was negative in the case of asset specificity, indicating that the benefit resulting from jointly building specific assets is less in environments of greater uncertainty, since assets represent committed investments that may lose value in a more uncertain environment. On the other hand, the interaction between uncertainty and relational governance was probably positive because the development of relational governance allows the dyad to be more adaptable to a changing environment, as is the case with the chemical industry. In turn, the direct effect of state uncertainty and the effect of the degree of competition and its interactions were 
not significant and did not support hypotheses $\mathrm{H} 4 \mathrm{c}, \mathrm{H} 5 \mathrm{a}$, and $\mathrm{H} 5 \mathrm{c}$.

In the regression whose dependent variable was the value coming from the relationship (VCR), asset specificity had a significant effect ( $p<0.05)$, thus supporting hypothesis $\mathrm{H} 1 \mathrm{c}$, although the same did not happen with the other two relational resources, thus not providing any support for hypotheses $\mathrm{H} 2 \mathrm{c}$ and $\mathrm{H} 3 \mathrm{c}$. Within the scope of the study, the presence of specific assets increases the perception that the relationship is valuable to the parties. This relationship can also be explained by the theory of transaction costs (Williamson, 2008). State uncertainty had no significant direct effect, not even through its interactions, thus not providing any support for hypotheses H4a and H4d. The degree of competition in the market had a negative and significant moderating effect $(p<0.01)$ on the relationship between asset specificity and the value coming from the relationship, thus supporting hypothesis $\mathrm{H} 5 \mathrm{a}$. This result indicates that the existence of specific assets is less effective when there is a greater degree of competition in the supplier market. The existence of other supply options, which in most cases occurs in the chemical industry, may reduce the benefits of assets that are jointly constructed for a specific relationship. We found no direct effects resulting from the degree of competition on the value coming from the relationship and no support for hypothesis $\mathrm{H} 5 \mathrm{~d}$.

Taken together, the results of the analyses show a limited effect of relational resources on the three value operationalizations, which is evident from the relatively small $\mathrm{R}^{2}$ (ranging from 15 to $25 \%)$. The direct effects of the relational resources were not significant, with the exception of asset specificity, which affected the value coming from the relationship (VCR), and relational governance for the value created for the supplier (VCS). The effect of relational resources by way of the interaction with environmental characteristics (uncertainty and degree of competition) was also limited. These results, combined with the lack of discriminant validity between knowledge sharing and resource complementarity (combined in the relationship practices construct), show the limitations of the relational view as an explanatory theory for value creation in relationships, which poses future challenges for investigating this relationship.

With regard to the context variables (state uncertainty and degree of competition), only uncertainty had a negative effect on the value created for the buyer, indicating that the buyer is most affected by the negative consequences of uncertainty. Both the value created for the supplier and the value coming from the relationship seem to be unaffected by uncertainty. The degree of competition did not affect any of the value operationalizations. Moderation of the effects of relational resources by context variables only occurs in specific cases and depends fundamentally on the type of value being considered. The context variables did not moderate the value created for the buyer. For the value created for the supplier, uncertain environments reduce the benefits derived from specific assets, and relational governance is more relevant in environments in which there is greater competition in the supplier market. For the value coming from the relationship, greater competition in the supplier market reduces the impact of specific assets on value creation.

The control variables generally had a limited effect. The length of the relationship between firms had a negative impact on the value coming from the relationship $(-0.30, \mathrm{p}<0.01)$. This correlation appears to be counterintuitive, but can be explained by the fact that the assessment reflects the perception of the supplier, which may consider that the investments it has been making to maintain the relationship are decreasing or, in its perception, have less impact for the buyer. We found no impact resulting from the sales variable, which is indicative of the size of the companies.

\section{Conclusion}

The limited support for the hypotheses tested suggests that the operationalization of the Relational View of Strategy as an explanatory 
theory needs to be looked into in greater depth. We do not generally find measurement models in the literature that use the four constructs, indicating that the limitations pointed out in this study may also have occurred in other papers. Asset specificity seems to be the most solid construct, with a relevant effect on the value coming from the relationship and being present in some of the moderating effects of the environmental variables. The results suggest that relational governance had some effect on the value created for the supplier, but the relationship practices that added the other two original constructs of the theoretical proposal (complementarity and knowledge sharing) had no effect in this research. These results add to other studies that also found it difficult to prove the predictions of the initial proposal of the relational view (for example, Chen et al., 2013; Hoetker $\&$ Mellewigt, 2009; Liu et al., 2009).

One theoretical possibility to be explored is the way in which the value created by the resources that are owned and controlled by one of the partners in a relationship can spill over to the other partner. In this scenario, the other partner, by appropriating the value captured in this specific relationship, would place itself in a position of competitive advantage in other relationships along the chain, thus transforming the original portion of the value created into various benefits that could not be enjoyed by the partner that generated it.

On the other hand, the proposed way of measuring value has contributed to a more complete and integrated understanding of relationships, by allowing different aspects of the value in relationships between the buyer and supplier to be identified. The value creation measurement scales that were proposed and tested in this study had good quality of fit and represent a contribution to future research. There are differences between the value created for the buyer and the value created for the supplier and, consequently, in the performance of each of them. There is also a portion of the value that comes from the relationship and takes form over the duration of the supply. This share is derived from collaborative processes that generate benefits for both parties. As the total value created is distributed among the different links in the chain, the value coming from the relationship ends up being transferred to the buyer or the supplier, thus increasing the share of value created for each of them (Brandenburger \& Stuart, 1996). These observations indicate that both parties in the dyad (buyer and supplier) can adopt isolated subprocesses and mechanisms to preserve the relational rents obtained, thereby changing the effects of the resources that originate from the relationship. A possible way of dealing with this is to introduce different theoretical approaches that help identify additional subprocesses and mechanisms for the relational view, which provide for a fairer development of the benefits generated by the relationship. From a management point of view, this study confirms the sharing of the value created between the parties in a relationship, indicating some factors that contribute to the definition of which direction this sharing takes, whether towards the buyer or towards the supplier of chemical products. Adequate use of relational resources can increase the share of value that each party captures in the relationship and can also leverage the mutual creation of value, which is beneficial to both. Careful observation of the environment in which the relationship is located, in terms of degrees of uncertainty and competition, is also a tool that can be used by practitioners when making decisions about the size of the investments to be made in that specific relationship.

New studies need to be undertaken to continue validating the measurement model used, by observing, correcting, and complementing any limitations that this study presented. Application of the scales in different industry sectors will help increase validation of the survey instrument, including enabling a reanalysis of the discriminant validity that was not observed between resource complementarity and knowledge sharing. Testing models that compete with the model we tested, 
where some constructs could be considered as precedent to others and not concomitant, as in the proposed model, will contribute to this validation process.

Regarding the limitations of this study, the sample size, compared to the number of independent variables, is low. The sample was also restricted to the supplier's point of view, although the study of the dyad, by applying the survey instrument to both parties, is a powerful tool for capturing the specificities of interorganizational relationships. This study could be expanded to involve larger samples, other industries, and other respondent profiles (buyers and dyads), thus contributing to the validity and reliability of the models and to the investigation and confirmation of the hypotheses. Industries such as personal care, food, and telecommunications have certain demand specificities and a wide variety of types of buyers and suppliers, which could help test the model in different scenarios in order to broaden the generalization of the conclusions.

\section{References}

Abdi, M., \& Aulakh, P. S. (2017). Locus of uncertainty and the relationship between contractual and relational governance in crossborder interfirm relationships. Journal of Management, 43(3), 771-803.

Acedo, F. J., Barroso, C., \& Galan, J. L. (2006). The resource-based theory: Dissemination and main trends. Strategic Management Journal, 27(7), 621-636

Adner, R., \& Zemsky, P. (2006). A demand-based perspective on sustainable competitive advantage. Strategic Management Journal, 27(3), 215-239.

Ambrose, E., Marshall, D., \& Lynch, D. (2010). Buyer supplier perspectives on supply chain relationships. International Journal of Operations \& Production Management, 30(12), 1269-1290.

Amit, R., \& Zott, C. (2001). Value creation in e-business. Strategic Management Journal, 22(67), 493-520.
Anderson, J. C, \& Gerbing, D. W. (1988) Structural equation modeling in practice: A review and recommended two step approach. Psychological Bulletin, 103(3), 411-423.

Armstrong, J. S., \& Overton, T. S. (1977) Estimating nonresponse bias in mail surveys. Journal of Marketing Research, 14(3), 396-402.

Balestrin, A., \& Arbage, A. P. (2007). A perspectiva dos custos de transação na formação de redes de cooperação. RAE-eletrônica, 6(1), art. 7 .

Barney, J., \& Clark, D. N. (2007). Resource-Based Theory. New York: Oxford.

Baltagi, B. H., Egger, P. H., \& Kesina, M. (2016). Firm-Level productivity spillovers in China's chemical industry: A Spatial Hausman-Taylor approach. Journal of Applied Econometrics, 31(1), 214-248.

Bentler, P. M., \& Bonett, D. G. (1980). Significance tests and goodness of fit in the analysis of covariance structures. Psychological Bulletin, 88(3), 588-606.

Brandenburger, A. M., \& Stuart Jr., H. W. (1996). Value-based business strategy. Journal of Economics \& Management Strategy, 5(1), 5-24.

Brito, E. P. Z., Brito, L. A. L., \& Morganti, F. (2009). Inovação e o desempenho empresarial: Lucro ou crescimento? RAE-eletrônica, 8(1), art. 6.

Brito, R. P., \& Brito, L. A. L. (2012). Vantagem competitiva e sua relação com o desempenho. Uma abordagem baseada em valor. Revista de Administração Contemporânea, 16(3), 360-380.

Brown, T. A. (2006). Confirmatory factor analysis for applied research. New York: Guilford Press.

Burgess, K., Singh, P. J., \& Koroglu, R. (2006). Supply chain management: A structured literature review and implications for future research. International Journal of Operations \& Production Management, 26(7), 703-729. 
Cao, M., \& Zhang, Q. (2011). Supply chain collaboration: Impact on collaborative advantage and firm performance. Journal of Operations Management, 29(3), 163-180.

Carifio, J., \& Perla, R. (2008). Resolving the 50 -year debate around using and misusing Likert scales. Medical Education, 42(12), 1150-1152.

Centenaro, A., \& Laimer, C. G. (2017). Relações de cooperação e a competitividade no setor supermercadista. Revista Brasileira de Gestão de Negócios, 19(63), 65-81.

Chatain, O. (2011). Value creation, competition, and performance in buyer-supplier relationships. Strategic Management Journal, 32(1), 76-102.

Chen, D. Q., Preston, D. S., \& Xia, W. (2013). Enhancing hospital supply chain performance: A relational view and empirical test. Journal of Operations Management, 31(6), 391-408.

Chen, J. I., \& Paulraj, A. (2004). Towards a theory of supply chain management: The constructs and measurements. Journal of Operations Management, 22(2), 119-150.

Cheung, M.-S., Myers, M. B., \& Mentzer, J. T. (2010). Does relationship learning lead to relationship value? A cross-national supply chain investigation. Journal of Operations Management, $28(6), 472-487$.

Coase, R. H. (1937). The nature of the firm. Economica New Series, 4(16), 386-405.

Cohen, W. M., \& Levinthal, D. A. (1990). Absorptive-capacity: A new perspective on learning and innovation. Administrative Science Quarterly, 35(1), 128-152.

Crook, T. R., \& Combs, J. G. (2007). Sources and consequences of bargaining power in supply chains. Journal of Operations Management, 25(2), 546-555.

Deboçã, L. P., \& Martins, R. S. (2015). Vantagens competitivas originadas dos relacionamentos horizontais em aglomeraçóes produtivas: Percepçôes de atores locais. Revista Brasileira de Gestão de Negócios, 17(56), 1025-1043.

Dyer, J. H. (1997). Effective interfirm collaboration: How firms minimize transactions costs and maximize transaction value. Strategic Management Journal, 18(7), 535-556.

Dyer, J. H., \& Chu, W. (2003). The role of trustworthiness in reducing transaction costs and improving performance: Empirical evidence from the United States, Japan, and Korea. Organization Science, 14(1), 57-68.

Dyer, J. H., \& Hatch, N. W. (2006). Relationspecific capabilities and barriers to knowledge transfers: Creating advantage through network relationships. Strategic Management Journal, 27(8), 701-719.

Dyer, J. H., \& Singh, H. (1998). The relational view: Cooperative strategy and sources of interorganizational competitive advantage. Academy of Management Review, 23(4), 660-679.

Dyer, J. H., Singh, H., \& Kale, P. (2008). Splitting the pie: Rent distribution in alliances and networks. Managerial and Decision Economics, 29(2-3), 137-148.

Edwards, J. R., \& Bagozzi, R. P. (2000). On the nature and direction of relationships between constructs and measures. Psychological Methods, 5(2), 155-174.

Flynn, B. B., Huo, B., \& Zhao, X. (2010). The impact of supply chain integration on performance: A contingency and configuration approach. Journal of Operations Management, 28(1), 58-71.

Fornell, C., \& Larcker, D. F. (1981). Evaluating structural equation models with unobservable variables and measurement error. Journal of Marketing Research. 18(1), 39-50. 
Forza, C. (2002). Survey research in operations management: A process-based perspective. International Journal of Operations \& Production Management, 22(2), 152-194.

Fouskas, K. G., \& Drossos, D. A. (2010). The role of industry perceptions in competitive responses. Industrial Management \& Data Systems, 110(4), 477-494.

Galembeck, F., Santos, A. C. M., Schumacher, H. C., Rippel, M. M., \& Rosseto, R. (2007). Indústria química: Evolução recente, problemas e oportunidades. Quimica Nova, 30(6), 1413-1419.

Hair, J. F., JR, Black, W. C., Babin, B. J., Anderson, R. E., \& Tatham, R. L. (2009). Análise multivariada de dados. Porto Alegre: Bookman.

Handley, S. M., \& Benton, W. C. (2012). The influence of exchange hazards and power on opportunism in outsourcing relationships. Journal of Operations Management, 30(1/2), 55-68.

Hernández-Espallardo, M., RodríguezOrejuela, A., \& Sánchez-Pérez, M. (2010). Inter-organizational governance, learning and performance in supply chains. Supply Chain Management: An International Journal, 15(2), 101-114.

Hitt, M. A., Xu, K., \& Carnes, C. M. (2016). Resource Based Theory in Operations Management Research. Journal of Operations Management, 41(12), 77-94.

Hoetker, G., \& Mellewigt, T. (2009). Choice and performance of governance mechanisms: matching alliance governance to asset type. Strategic Management Journal, 30(10), 10251044.

Hoffmann, P., Schiele, H., \& Krabbendam, K. (2013). Uncertainty, supply risk management and their impact on performance. Journal of Purchasing and Supply Management, 19(3), 199211.
Huemer, L. (2014). Creating cooperative advantage: The roles of identification, trust, and time. Industrial Marketing Management, 43(4), 564-572.

Hult, G. T. M., Ketchen Jr, D. J., \& Arrfelt, M. (2007). Strategic supply chain management: Improving performance through a culture of competitiveness and knowledge development. Strategic Management Journal, 28(10), 1035-1052.

Jap, S. D. (1999). Pie-expansion efforts: Collaboration processes in buyer-supplier relationships. Journal of Marketing Research, 36(4), 461-475.

Jayaraman, V., Narayanan, S., Luo, Y., \& Swaminathan, J. M. (2013). Offshoring business process services and governance control mechanisms: An examination of service providers from India. Production and Operations Management, 22(2), 314-334.

Jöreskog, K. G. (1993). Testing Structural Equation Models. In: Bollen, K. A., Long, J. S. (Ed.). Testing Structural Equation Models. Newbury Park: Sage Publications, 294-316.

Kale, P., Singh, H., \& Perlmutter, H. (2000). Learning and protection of proprietary assets in strategic alliances: Building relational capital. Strategic Management Journal, 21(3), 217-237.

Kang, M-P., Mahoney, J. T., \& Tan, D. (2009). Why firms make unilateral investments specific to other firms: The case of OEM suppliers. Strategic Management Journal, 30(2), 117-135.

Kim, Y., \& Choi, T. Y. (2015). Tie strength and value creation in the buyer-supplier context: A U-shaped relation moderated by dependence asymmetry. Journal of Management, p. 0149206315599214.

Kline, R. B. (2005). Principles and practice of structural equation modeling. New York, USA: The Guilford Press. 
Kozlenkova, I. V., Samaha, S. A., \& Palmatier, R. W. (2014). Resource-based theory in marketing. Journal of the Academy of Marketing Science, 42(1), $1-21$.

Krause, D. R., Handfield, R. B., \& Tyler, B. B. (2007). The relationships between supplier development, commitment, social capital accumulation and performance improvement. Journal of Operations Management, 25(2), 528-545.

Kumar, G., Banerjee, R. N., Meena, P. L., \& Ganguly, K. (2016). Collaborative culture and relationship strength roles in collaborative relationships: A supply chain perspective. Journal of Business \& Industrial Marketing, 31(5), 587599.

Leite, R. S, Lopes, H. E. G., \& Silva, S. A. D. (2009). A estratégia em relacionamentos coopetitivos: Um estudo do arranjo produtivo de Nova Serrana. Revista Brasileira de Gestão de Negócios, 11(30), 65-78.

Li, L., Jiang, F., Pei, Y., \& Jiang, N. (2017). Entrepreneurial orientation and strategic alliance success: The contingency role of relational factors. Journal of Business Research, 72, 46-56.

Lin, Z., Yang, H., \& Arya, B. (2009). Alliance partners and firm performance: Resource complementarity and status association. Strategic Management Journal, 30(9), 921-940.

Lindgreen, A., \& Wynstra, F. (2005). Value in business markets: What do we know? Where are we going? Industrial Marketing Management, 34(7), 732-748.

Liu, Y., Luo, Y., \& Liu, T. (2009). Governing buyer-supplier relationships through transactional and relational mechanisms: Evidence from China. Journal of Operations Management, 27(4), 294309.

McDonald, R. P., \& Ho, M. H. R. (2002). Principles and practice in reporting structural equation analyses. Psychological Methods, 7(1), 64-82.

Mena, C., Humphries, A., \& Choi, T. Y. (2013). Toward a theory of multi-tier supply chain management. Journal of Supply Chain Management, 49(2), 58-77.

Mesquita, L. F., Anand, J., \& Brush, T. H. (2008). Comparing the resource-based and relational views: Knowledge transfer and spillover in vertical alliances. Strategic Management Journal, 29(9), 913-941.

Miguel, P. L. S., Brito, L. A. L., Fernandes, A. R., Tescari, F. C., \& Martins, G. S. (2014). Relational value creation and appropriation in buyer-supplier relationships. International Journal of Physical Distribution \& Logistics Management, 44(7), 559-576.

Milliken, F. J. (1987). Three types of perceived uncertainty about the environment: State, effect, and response uncertainty. The Academy of Management Review, 12(1), 133-143.

Moori, R. G., Shibao, F. Y., \& Kimura, H. (2016). Efeito moderador da inovação verde sobre gestão da cadeia de suprimentos e desempenho. Gestão \& Regionalidade (Online), 32(96).

Nahm, A. Y., Rao, S. S., Solis-Galvan, L. E., \& Ragu-Nathan, T. S. (2002). The Q-sort method: Assessing reliability and construct validity of questionnaire items at a pre-testing stage. Journal of Modern Applied Statistical Methods, 1(1), 114125.

Narasimhan, R., \& Nair, A. (2005). The antecedent role of quality, information sharing and supply chain proximity on strategic alliance formation and performance. International Journal of Production Economics, 96(3), 301-313.

Norman, G. (2010). Likert scales, levels of measurement and the "laws" of statistics. Advances in Health Sciences Education, 15(5), 625-632. 
O'Cass, A., \& Weerawardena, J. (2010). The effects of perceived industry competitive intensity and marketing-related capabilities: Drivers of superior brand performance. Industrial Marketing Management, 39(4), 571-581.

Palmatier, R. W., Dant, R. P., \& Grewal, D. (2007). A comparative longitudinal analysis of theoretical perspectives of interorganizational relationship performance. Journal of Marketing, 71(4), 172-194.

Peng, D. X., \& Lai, F. (2012). Using partial least squares in operations management research: A practical guideline and summary of past research. Journal of Operations Management, 30(6), 467-480.

Pereira, B. A. D., \& Pedrozo, E. A. (2005). Contribuiçóes à consolidação da Teoria Estratégica Interorganizacional: Uma análise dos relacionamentos horizontais. Revista de Administração Contemporânea, 9(4), 141-161.

Peteraf, M. A., \& Barney, J. B. (2003). Unraveling the resource-based tangle. Managerial and Decision Economics, 24(4), 309-323.

Priem, R. L., Li, S., \& Carr, J. C. (2012). Insights and new directions from demand-side approaches to technology innovation, entrepreneurship, and strategic management research. Journal of Management, 38(1), 346-374.

Proch, M., Worthmann, K., \& Schlüchtermann, J. (2017). A negotiation-based algorithm to coordinate supplier development in decentralized supply chains. European Journal of Operational Research, 256(2), 412-429.

Podsakoff, P. M., MacKenzie, S. B., Lee, J. Y., \& Podsakoff, N. P. (2003). Common method biases in behavioral research: A critical review of the literature and recommended remedies. Journal of Applied Psychology, 88(5), 879-903.

Podsakoff, P. M., \& Organ, D. W. (1986). Selfreports in organizational research: Problems and prospects. Journal of Management, 12(4), 531544.

Pulles, N. J., Schiele, H., Veldman, J., \& Hüttinger, L. (2016). The impact of customer attractiveness and supplier satisfaction on becoming a preferred customer. Industrial Marketing Management, 54, 129-140.

Rezende, S. F. L., Lima, W. M. A., \& Versiani, A. F. (2012). Evolução de conhecimentos no relacionamento comprador-fornecedor. Revista de Administração Contemporânea, 16(1), 39-58.

Santos, L. D., \& Amaral, L. A. M. (2004). Estudos Delphi com Q-sort sobre a Web - A sua utilização em Sistemas de Informação. In Actas da $5^{a}$ Conferência da Associação Portuguesa de Sistemas de Informação, Lisboa, Portugal, (14 páginas).

Shavit, T., Rosenboim, M., \& Malul, M. (2011). Opportunity costs in buying and short selling. Do they really matter? Economics Letters, 112(1), 122-124.

Shervani, T. A., Frazier, G., \& Challagalla, G. (2007). The moderating influence of firm market power on the transaction cost economics model: An empirical test in a forward channel integration context. Strategic Management Journal, 28(6), 635-652.

Speier, C., Whipple, J. M., Closs, D. J., \& Voss, M. D. (2011). Global supply chain design considerations: Mitigating product safety and security risks. Journal of Operations Management, 29(7), 721-736.

Tang, X., \& Rai, A. (2012). The moderating effects of supplier portfolio characteristics on the competitive performance impacts of supplierfacing process capabilities. Journal of Operations Management, 30(1-2), 85-98.

Tanskanen, K., \& Aminoff, A. (2015). Buyer and supplier attractiveness in a strategic relationship. A dyadic multiple-case study. Industrial Marketing Management, 50, 128-141. 
Tescari, F. C., \& Brito, L. A. L. (2016). Value creation and capture in buyer-supplier relationships: A new perspective. Revista de Administração de Empresas, 56(5), 474-488.

Williamson, O. E. (2008). Outsourcing: Transaction cost economics and supply chain management. Journal of Supply Chain Management, 44(2), 5-16.

Wong, C. Y., Boon-Itt, S., \& Wong, C. W. Y. (2011). The contingency effects of environmental uncertainty on the relationship between supply chain integration and operational performance.
Journal of Operations Management, 29(6), 604615.

Zacharias, N. A., Nijssen, E. J., \& Stock, R. M. (2016). Effective configurations of value creation and capture capabilities: Extending Treacy and Wiersema's value disciplines. Journal of Business Research, 69(10), 4121-4131.

Zajac, E. J., \& Olsen, C. P. (1993) From transaction cost to transaction value analysis: Implications for the study of interorganizational strategies. Journal of Management Studies, 30(1), 131-145. 


\section{APPENDIX 1 - SCALES USED AND FACTOR LOADINGS}

\section{Value created for the supplier (Crook \& Combs, 2007; Krause, Handfield, \& Tyler, 2007; Palmatier et al., 2007)}

If the relationship with this customer were to be interrupted and your company had to replace this volume in the market: (I totally disagree / I fully agree)

\begin{tabular}{|l|c|}
\hline \multicolumn{1}{|c|}{ Item } & Loading \\
\hline Your company would find it difficult to replace this volume. & 0.86 \\
\hline $\begin{array}{l}\text { Your company would find it difficult to replace the volume and keep the same } \\
\text { margin. }\end{array}$ & 0.74 \\
\hline $\begin{array}{l}\text { Your company would suffer a negative impact in the market because of the } \\
\text { relevance of this customer. }\end{array}$ & 0.54 \\
\hline $\begin{array}{l}\text { Your company would have to spend time and relevant effort to develop (an) } \\
\text { equivalent customer(s). }\end{array}$ & 0.79 \\
\hline
\end{tabular}

Value created for the buyer (Crook \& Combs, 2007; Krause, Handfield, \& Tyler, 2007; Palmatier et al., 2007)

In the hypothetical situation of an interruption in your supply, if the customer had to look for another supplier (I totally disagree / I fully agree)

\begin{tabular}{|l|c|}
\hline \multicolumn{1}{|c|}{ Item } & Loading \\
\hline It would lose a relevant source of competitiveness. & 0.75 \\
\hline It would lose the gains obtained. & 0.95 \\
\hline $\begin{array}{l}\text { It would have to spend time and relevant effort to develop (an) equivalent } \\
\text { supplier(s). }\end{array}$ & 0.67 \\
\hline
\end{tabular}

\section{Value coming from the relationship (Chatain, 2011; Jap, 1999)}

How do you assess the evolution of the relationship with this customer over the last few years? (It has consistently reduced / it has consistently improved)

\begin{tabular}{|l|c|}
\hline \multicolumn{1}{|c|}{ Item } & Loading \\
\hline The benefits our company has with this customer. & 0.84 \\
\hline The relevance of this customer to my business. & 0.75 \\
\hline $\begin{array}{l}\text { The contribution to my business arising from the improvements developed } \\
\text { jointly with this customer. }\end{array}$ & 0.78 \\
\hline
\end{tabular}




\section{Asset specificity (Kang, Mahoney, \& Tan, 2009)}

Assess the intensity of your company's investments for this specific relationship: (Minimal investment / heavy investment)

\begin{tabular}{|l|c|}
\hline \multicolumn{1}{|c|}{ Item } & Loading \\
\hline $\begin{array}{l}\text { Your company has been investing time with this customer to get to know its } \\
\text { operating routines and to build relationships with its employees. }\end{array}$ & 0.59 \\
\hline $\begin{array}{l}\text { Your company has been adjusting its products and production systems in order } \\
\text { to adapt to the special needs and differentiated technical specifications this } \\
\text { customer requires. }\end{array}$ & 0.83 \\
\hline $\begin{array}{l}\text { Your company has been investing time and effort in coordinating operational } \\
\text { processes with your suppliers in order to adapt to the special needs and } \\
\text { differentiated technical specifications this customer requires. }\end{array}$ & 0.76 \\
\hline
\end{tabular}

\section{Relationship practices (Cao \& Zhang, 2011; Cheung et al., 2010)}

Indicate your degree of agreement with the following statements: (I totally disagree / I fully agree)

\begin{tabular}{|l|c|}
\hline \multicolumn{1}{|c|}{ Item } & Loading \\
\hline Our company and this customer have frequent contacts on a regular basis. & 0.51 \\
\hline Our company and this customer have open and two-way communication. & 0.76 \\
\hline $\begin{array}{l}\text { The competences brought to the relationship by each of the companies have } \\
\text { been very valuable to the other party. }\end{array}$ & 0.75 \\
\hline Our company and this customer share common objectives and goals. & 0.67 \\
\hline $\begin{array}{l}\text { There is correspondence between the philosophies and approaches of both } \\
\text { companies when doing business. }\end{array}$ & 0.55 \\
\hline
\end{tabular}

\section{Relational governance (Jap, 1999)}

Indicate your degree of agreement with the following statements: (I totally disagree / I fully agree)

\begin{tabular}{|l|c|}
\hline \multicolumn{1}{|c|}{ Item } & Loading \\
\hline Our promises to this customer are trustworthy. & 0.70 \\
\hline Our company would make every effort to help this customer. & 0.71 \\
\hline We consider the interests of this customer when problems arise. & 0.70 \\
\hline
\end{tabular}

\section{State uncertainty (Cheung et al., 2010)}

Indicate your agreement with the following statements on the industry of the main product sold to this customer: (I totally disagree / I fully agree - inverted)

\begin{tabular}{|l|c|}
\hline \multicolumn{1}{|c|}{ Item } & Loading \\
\hline The market share of your company is stable. & 0.46 \\
\hline The sales volume in this industry is stable. & 0.73 \\
\hline The sales forecasts are accurate. & 0.67 \\
\hline
\end{tabular}




\section{Degree of competition in the supply market (O’Cass \& Weerawardena, 2010)}

Indicate your agreement with the statements about the suppliers of products that are equivalent to the main product sold to this customer: (I totally disagree / I fully agree)

\begin{tabular}{|l|c|}
\hline \multicolumn{1}{|c|}{ Item } & Loading \\
\hline The companies compete intensely. & 0.75 \\
\hline The industry is characterized by price competition. & 0.51 \\
\hline The industry is characterized by price cutting. & 0.46 \\
\hline Competition is intense and fierce. & 0.85 \\
\hline
\end{tabular}

\section{Notes:}

1 Article derived from the masters thesis titled «Creating value in the relationship between chemical companies and their clients» by Fábio Campos Tescari, mentored by Prof. Dr. Luiz Artur Ledur Brito, Fundação Getúlio Vargas, Escola de Administração de Empresas de São Paulo, São Paulo, 2013.

\section{Supporting Agencies:}

The authors acknowledge and thank the financial support from Fundaçáo de Amparo à Pesquisa do Estado de São Paulo (FAPESP).

\section{About the Authors:}

1. Fábio Campos Tescari, $\mathrm{PhD}$ in Business Administration, Fundação Getúlio Vargas, Brazil.

E-mail:fabio.tescari@gmail.com.

\section{ORCIID}

(iD) 0000-0002-3065-7762

2. Luiz Artur Ledur Brito, $\mathrm{PhD}$ in Business Administration, Fundação Getúlio Vargas, Brazil.

E-mail:luiz.brito@fgv.br.

\section{ORCIID}

(iD) 0000-0001-9782-074X

\section{Contribution of each author:}

\begin{tabular}{lcc}
\hline Contribution & Fábio Tescari & Luiz Brito \\
\hline 1. Definition of research problem & $\sqrt{ }$ & $\sqrt{ }$ \\
2. Development of hypotheses or research questions (empirical studies) & $\sqrt{ }$ & $\sqrt{ }$ \\
3. Development of theoretical propositions (theoretical work) & NA & $\sqrt{ }$ \\
4. Theoretical foundation/Literature review & $\sqrt{ }$ & $\sqrt{ }$ \\
5. Definition of methodological procedures & $\sqrt{ }$ \\
6. Data collection & $\sqrt{ }$ \\
7. Statistical analysis & $\sqrt{ }$ & $\sqrt{ }$ \\
8. Analysis and interpretation of data & $\sqrt{ }$ \\
9. Critical review of the manuscript & $\sqrt{ }$ \\
10. Manuscript writing & $\sqrt{ }$ & $\sqrt{ }$ \\
\hline
\end{tabular}


Fábio Campos Tescari / Luiz Artur Ledur Brito 
The Relational View: Future challenges for a non-confirmed expectation 
Fábio Campos Tescari / Luiz Artur Ledur Brito

490 
The Relational View: Future challenges for a non-confirmed expectation 
Fábio Campos Tescari / Luiz Artur Ledur Brito 